\title{
Pemanfaatan Media Pembelajaran Berbasis ICT pada Lembaga Pendidikan Non-Formal TPQ
}

\author{
Muslih \\ Universitas Islam Negeri Walisongo Semarang
}

\begin{abstract}
It is the fact that technology has developed rapidly today. Such a development has influenced communication pattern among people, including communication in the field of education, particularly the process of instruction in a class between teacher and student. Audio visual aids began to be utilized to deliver educational messages. In this case, these audio visual aids were functioned not merely as device aids in education but more than that they can function as an effecitve educational message deliverer. To support the success of teaching and learning process in a class, the utilization of audio visual aids need to be maximized. The utilization of instructional media, especially the ones based on Information and Communication Technology (ICT) is a must and need to be adopted by all teachers today if they wish to have effective and efficient instructions. This is valid for not only teachers who work in formal educational institution like a school, but also for teachers working in non-formal educational institution such as educational park of the Quran (TPQ).
\end{abstract}

Abstrak: Dewasa ini teknologi telah mengalami perkembangan yang begitu cepat. Perkembangan tersebut ikut mempengaruhi pola komunikasi antar manusia, termasuk komunikasi dalam dunia pendidikan khususnya proses pembelajaran di kelas yang melibatkan guru dan murid. Alat-alat audio visual tersebut dipergunakan tidak saja sebagai alat bantu pendidikan namun lebih dari itu ia berfungsi sebagai penyampai pesan-pesan pendidikan yang efektif. Untuk menunjang keberhasilan kegiatan belajar mengajar di kelas penggunaan alat-alat audio visual tersebut harus dimaksimalkan pemanfaatannya. Pemanfaatan media pembelajaran khususnya yang berbasis pada Information and Communication Technology (ICT) sekarang ini sudah menjadi keharusan yang harus dijalani oleh setiap guru apabila menginginkan pembelajaran yang efektif dan efisien.Hal ini berlaku tidak saja bagi guru yang bekerja di 
lembaga pendidikan formal tapi juga di pendidikan non-formal seperti guru di Taman Pendidikan Al-Quran (TPQ).

Kata Kunci: Pembelajaran, Media, ICT, Pendidikan, Kelas, Guru.

\section{PENDAHULUAN}

Seiring dengan perkembangan zaman yang semakin maju kondisi di dalam dunia pendidikan juga mengalami pergeseran. Peran guru sebagai penyampai pesan-pesan sudah harus ditopang dengan media pendidikan yang baik agar proses pembelajaran yang dilakukannya berlangsung secara efektif dan efisien. Hal tersebut dikarenakan materi yang harus disampaikan oleh guru kepada peserta didik semakin hari semakin luas dan beragam cakupannya.Berbeda keadaannya dari masa lampau dimana guru menjadi sumber belajar utama dan satu-satunya kini kondisinya sudah berubah.Sejak memasuki separuh akhir abad ke-20 dimana teori komunikasi sosial mulai masuk ke dalam ranah dunia pendidikan, alat-alat bantu pandang dengar (audio visual aids) mulai dipergunakan dalam penyampaian pesan-pesan pendidikan. Media pendidikan yang berupa alat-alat tersebut dipandang tidak saja sebagai alat bantu pendidikan, melainkan juga berfungsi sebagai penyampai pesan-pesan pendidikan yang efektif.Penggunaan alat-alat bantu atau media pembelajaran dalam dunia pendidikan sudah menjadi keharusan yang mesti ditempuh oleh setiap guru. Penerapan media pembelajaran di kelas sangat membantu keberhasilan guru dalam proses belajar mengajar. Hal ini berlaku untuk guru-guru di semua jalur pendidikan, baik itu formal maupun non-formal.

Artikel ini menyajikan pembahasan tentang pemanfaatan media pembelajaran berbasis Information and Communication Technology (ICT) pada lembaga pendidikan non-formal TPQ. Tulisan ini sengaja membatasi diri hanya membahas pemanfaatan media ICT di kelas TPQ karena didasarkan pada hasil karya pengabdian yang penulis lakukan di 2016 pada guru-guru TPQ di kecamatan Ngaliyan kota Semarang. Supaya diskusinya lebih fokus maka pembahasan dalam paper ini diarahkan untuk menjawab rumusan masalah yang diangkat dengan tulisan ini, yang meliputi poin-poin berikut: apa yang dimaksud dengan media pembelajaran, apa itu media pembelajaran berbasis ICT, dan dapatkah diupayakanpembelajaran berbasis ICT pada lembaga pendidikan nonformal seperti TPQ. Masalah-masalah tersebut akan diuraikan secara sistematis pada sub-sub pembahasan tulisan ini sebagai berikut. 


\section{MEDIA PEMBELAJARAN}

Media pembelajaran sering juga disebut dengan istilah media pendidikan. Kedua istilah ini bisa dipergunakan secara bergantian dan mengandung makna yang relatifsama.Media pembelajaran merupakan suatu alat atau perantara yang berguna untuk memudahkan proses belajar mengajar, dalam rangka mengefektifkan komunikasi antara guru dan murid. Hal ini sangat membantu guru dalam mengajar dan memudahkan murid menerima dan memahami pelajaran.Perlu ditekankan bahwa proses ini membutuhkan peran guru yang profesional agar mampu menyelaraskan antara media pembelajaran dan metode pendidikan.

Media pendidikan mempunyai fungsi yang besar di berbagai kehidupan, baik di dalam dunia pendidikan maupun dalam kehidupan sosial, ekonomi, maupun seni budaya. ${ }^{1}$ Dalam kehidupan pendidikan media komunikasi memberikan kontribusi yang besar dalam kemajuan maupun peningkatan mutu di suatu lembaga pendidikan. Dengan memakai media tersebut anak didik akan mudah mencerna dan memahami suatu pelajaran. Dengan demikian melalui pendekatan ilmiah sistematis, dan rasional tujuan pendidikan dapat dicapai secara efektif dan efisien. ${ }^{2}$

Untuk mencapai tujuan pendidikan tersebut guru memiliki peran yang penting untuk menghantarkan keberhasilan anak didik,oleh karenanya dibutuhkan komunikasi yang baik antara guru dan murid. Untuk menciptakan komunikasi yang baik dibutuhkan guru yang profesional yang mampu menyeimbangkan antara media pembelajaran dan metode pengajaran sehingga informasi yang disampaikan guru dapat diterima siswa dengan baik. ${ }^{3}$

Secara harfiah media diartikan sebagai "perantara" atau "pengantar". AECT (Association for Educational Communications and Technology) mendefinisikan media sebagai segala bentuk yang digunakan untuk proses penyaluran informasi. ${ }^{4}$ Robert Hanick dan kawan-kawan mendefinisikan media sebagai sesuatu yang membawa informasi antara sumber (source) dan penerima (receiver) informasi.Sementara itu, Kemp dan Dayton mengemukakan peran media dalam proses komunikasi sebagai alat pengirim (transfer) yang mentransmisikan pesan dari pengirim (sender) kepada penerima pesan atau informasi (receiver). ${ }^{5}$ Media

\footnotetext{
${ }^{1}$ S. Nasution, Teknologi Pendidikan, Bandung: Jemars, 1983. Lihat juga H. Asnawir, Media Pendidikan, Jakarta: Ciputat Pers, 2002.

2 Sudarman Danim, Media Komunikasi Pendidikan, Jakarta: Bumi Aksara, 1995.

IIbid., hlm. 7.

${ }^{4}$ Ibid., hlm. 11.

${ }_{5}^{5}$ Benni Agus Pribadi, Media Pendidikan, Jakarta: Universitas Terbuka, 1996.
} 
pembelajaran merupakan perantara atau alat untuk memudahkan proses belajar mengajar agar tujuan pengajaran tercapai secara efektif dan efisien. Jadi dengan demikian dapat disimpulkan bahwa media pembelajaran adalah alat, metodik dan teknik yang digunakan sebagai perantara komunikasi antara seorang guru dan murid dalam rangka lebih mengefektifkan komunikasi dan interaksi antara guru dan murid dalam proses pendidikan pengajaran di sekolah.

\section{SUMBER BELAJAR, MEDIA PEMBELAJARAN DAN ALAT PERAGA}

Dalam pembahasan mengenai media pembelajaran ada beberapa istilah yang saling berkaitan.Untuk memperoleh pemahaman yang benar maka perlu dipertegas dan dijelaskan beberapa istilah tersebut.Pertama adalahsumber belajar,yang merupakan sumber daya yang didesain atau dimanfaatkan untuk kepentingan proses belajar, baik langsung maupun tidak langsung, sebagian atau seluruhnya. AECT mengelompokkan sumber belajar ke dalam enam kelompok besar, yakni:

Tabel 1

\begin{tabular}{|c|c|c|c|}
\hline \multirow{2}{*}{$\begin{array}{c}\text { Jenis Sumber } \\
\text { Belajar }\end{array}$} & \multirow[b]{2}{*}{ Pengertian } & \multicolumn{2}{|c|}{ Contoh } \\
\hline & & By Design & $\begin{array}{c}\text { By } \\
\text { Utilization }\end{array}$ \\
\hline $\begin{array}{l}\text { Pesan } \\
\text { (Mesasage) }\end{array}$ & $\begin{array}{l}\text { Informasi yang harus } \\
\text { disalurkan oleh komponen } \\
\text { lain berbentuk ide, fakta, } \\
\text { pengertian atau data. }\end{array}$ & $\begin{array}{l}\text { Bahan-bahan } \\
\text { pelajaran. }\end{array}$ & $\begin{array}{l}\text { Cerita rakyat, } \\
\text { dongeng, } \\
\text { nasehat. }\end{array}$ \\
\hline $\begin{array}{l}\text { Manusia } \\
\text { (People) }\end{array}$ & $\begin{array}{l}\text { Orang yang menyimpan } \\
\text { informasi atau } \\
\text { menyalurkannya (tidak } \\
\text { termasuk yang } \\
\text { menjalankan fungsi } \\
\text { pengamanan dan } \\
\text { pengelolaan sumber } \\
\text { belajar). }\end{array}$ & $\begin{array}{l}\text { Guru, aktor, } \\
\text { peserta didik, } \\
\text { pemain (tidak } \\
\text { termasuk } \\
\text { teknisi, tim } \\
\text { kurikulum). }\end{array}$ & $\begin{array}{l}\text { Narasumber, } \\
\text { pemuka } \\
\text { masyarakat, } \\
\text { pimpinan } \\
\text { instansi, } \\
\text { responden. }\end{array}$ \\
\hline $\begin{array}{l}\text { Bahan } \\
\text { (Materials) }\end{array}$ & $\begin{array}{l}\text { Sesuatu, bisa disebut media } \\
\text { perangkat lunak, yang } \\
\text { mengandung pesan untuk } \\
\text { disajikan. }\end{array}$ & $\begin{array}{l}\text { Transparan, } \\
\text { slide, tape, } \\
\text { buku, gambar. }\end{array}$ & $\begin{array}{l}\text { Masjid, buku, } \\
\text { peralatan } \\
\text { teknik. }\end{array}$ \\
\hline $\begin{array}{l}\text { Peralatan } \\
\text { (Devices) }\end{array}$ & $\begin{array}{l}\text { Sesuatu, bisa disebut media } \\
\text { perangkat keras, yang } \\
\text { mendukung penyampaian }\end{array}$ & $\begin{array}{l}\text { OHP, TV, } \\
\text { kamera, papan } \\
\text { tulis. }\end{array}$ & $\begin{array}{l}\text { Generator, } \\
\text { mesin, alat-alat } \\
\text { mobil. }\end{array}$ \\
\hline
\end{tabular}




\begin{tabular}{|l|l|l|l|}
\hline & pesan yang disajikan. & & \\
\hline $\begin{array}{l}\text { Metode/teknik } \\
\text { (Techniques) }\end{array}$ & $\begin{array}{l}\text { Prosedur yang disiplin } \\
\text { dalam memanfaatkan } \\
\text { bahan, peralatan atau } \\
\text { situasi untuk } \\
\text { menyampaikan pesan. }\end{array}$ & $\begin{array}{l}\text { Ceramah, } \\
\text { diskusi, } \\
\text { simulasi, } \\
\text { belajar } \\
\text { mandiri. }\end{array}$ & $\begin{array}{l}\text { Permainan, } \\
\text { sarasehan, } \\
\text { percakapan } \\
\text { spontan, dll. }\end{array}$ \\
\hline $\begin{array}{l}\text { Lingkungan } \\
\text { (Settings) }\end{array}$ & $\begin{array}{l}\text { Situasi sekitar dimana } \\
\text { pesan disampaikan. }\end{array}$ & $\begin{array}{l}\text { Ruang kelas, } \\
\text { studio, aula. }\end{array}$ & $\begin{array}{l}\text { Taman, kebun, } \\
\text { pasar, } \\
\text { museum. }\end{array}$ \\
\hline
\end{tabular}

Kedua adalah media belajar, yang memiliki banyak batasan. AECT, misalnya membatasi media sebagai segala bentuk dan saluran yang digunakan orang untuk menyalurkan pesan/informasi. Gagne (1970) menyatakan bahwa media adalah berbagai jenis komponen dalam lingkungan peserta didik yang dapat merangsangnya untuk belajar.Sementara itu Briggs (1970) menyatakan media adalah segala alat fisik yang dapat menyajikan pesan serta merangsang peserta didik untuk belajar. Sementara itu, NEA (National Education Association/ Assosiasi Pendidikan Nasional) menyatakan bahwa media adalah segala sesuatu yang dapat digunakan untuk menyalurkan pesan dari pengirim ke penerima sehingga dapat merangsang pikiran, perasaan, perhatian dan minat serta perhatian peserta didik sedemikian rupa sehingga proses belajar terjadi. ${ }^{6}$

Di dalam memilih media pembelajaran ini setidaknya ada tujuh kriteria yang harus diperhatikan, yakni: a) Kesesuaian. Media pembelajaran itu dipilih karena dapat membantu peserta didik memperoleh pemahaman atas materi yang diajarkan guru dan sesuai dengan kompetensi yang akan dicapai. b) Objektivitas. Pemilihan media harus dilakukan secara objektif, tidak boleh didasarkan atas kesenangan pribadi. c) Sasaran program.Media pembelajaran yang dipilih harus disesuaikan dengan tingkat pemahaman dan perkembangan peserta didik. d) Tingkat kesulitan.Pemilihan media perlu mempertimbangkan tingkat kesulitan yang dihadapi oleh guru dalam penggunaannya. e) Biaya. Pemilihan dan penggunaan media pembelajaran perlu mempertimbangkan besar kecilnya biaya yang harus dikeluarkan dibandingkan dengan hasil yang akan dicapai. f) Ketersediaan.Pemilihan dan penggunaan media pembelajaran perlu mempertimbangkan ketersediaannya. Dan g) Kualitas teknis.Media pembelajaran yang digunakan hendaknya yang berkualitas tinggi.

${ }^{6}$ Sadiman, Arief S., dkk. Media pendidikan: pengertian, pengembangan, dan pemanfaatannya. Jakarta: PT Raja Grafindo Persada, 2012, hlm. 6. 
Perlu ditekankan bahwa media pembelajaran tidak terbatas pada alat-alat audio-visualsaja melainkan juga mencakup hal-hal yang berupa tingkah laku termasuk pula di dalamnya pribadi dan tingkah laku guru.

Secara umum, bentuk media pembelajaran bisa berupa: (a) Bahan-bahan catatan atau bacaan, contohnya seperti buku, komik, koran, majalah, bulletin, folder, periodikal dan pamflet, dan lain-lain. (b) Alat-alat audio-visual, yang meliputi: 1) Media pembelajaran tanpa proyeksi, misalnya papan tulis, papan tempel, papan planel, bagan diagram, grafik, karton, komik, gambar, 2) Media pembelajaran tiga dimensi seperti benda asli dan benda tiruan, misalnya diorama, boneka, dan lain-lain, 3) Media yang menggunakan teknik atau masinal, misalnya film strip, film, radio, televisi, laboratorium elektro perkakas atau instruktif, ruang kelas otomotif dan komputer. (c) Sumber-sumber masyarakat,termasuk dalam kategori ini adalah obyek-obyek, peninggalan sejarah, dokumentasi (tentang suatu peristiwa), bahan-bahan bekas, dan sebagainya. (d) Kumpulan benda-benda, yakni benda-benda yang dibawa dari masyarakat ke sekolah untuk dipelajari, misalnya potongan kaca, benih, bibit, bahan kimia, darah dan lain-lain. (e) Contoh-contoh kelakuan yang dicontohkan oleh guru.Meliputi semua contoh kelakuan yang dipertunjukkan oleh guru waktu mengajar, misalnya dengan tangan, kaki, gerakan badan, mimik, dan lain-lain.

Ketiga adalah alat peraga, yang dalam konteks pembelajaran dipahami sebagai nilai manfaat, dalam arti segala sesuatu alat yang dapat menunjang keefektifan dan efesiensi penyampaian, pengembangan dan pemahaman informasi atau pesan pembelajaran. Sebagai ilustrasi, misalnya Pak Budi akan mengajarkan bagaimana gambar dalam televisi bisa terlihat di layar. Maka Pak Budi membawa televisi ke kelas, kemudian ia membukanya di depan kelas, lalu menjelaskan satu-persatu fungsi dari masing-masing komponen televisi tersebut kepada siswa sehingga siswa memahami kenapa gambar terlihat pada layar televisi. Dalam ilustrasi tersebut kedudukan televisi adalah sebagai alat peraga, bukan sebagai media.

Terlepas dari perbedaan pemahaman tentang tiga istilah di atas, pada dasarnya baik sumber belajar, media pembelajaran maupun alat peraga memiliki esensi penting jika ketiganya diintegrasikan dalam proses pembelajaran, dimana esensi pentingnya adalah informasi. Jadi informasi yang terkandung, yang melalui, yang diolah, atau yang disampaikan, semuanya akan mempengaruhi daya dukung keberhasilan ketiganya dalam upaya meningkatkan kualitas pembelajaran yang dimaksud.

Pada mulanya media hanya dikenal sebagai alat bantu dalam kegiatan belajar mengajar yakni memberikan pengalaman visual pada anak dalam rangka 
mendorong motivasi belajar, memperjelas, dan mempermudah konsep yang komplek dan abstrak menjadi lebih sederhana, konkret, mudah dipahami. Dewasa ini dengan perkembangan teknologi serta pengetahuan, maka media pembelajaran berfungsi sebagai berikut; Membantu memudahkan belajar bagi siswa dan juga memudahkan pengajaran bagi guru. Memberikan pengalaman lebih nyata (abstrak menjadi konkret). Menarik perhatian siswa lebih besar sehingga pembelajaran tidak membosankan. Semua indera murid dapat diaktifkan. Lebih menarik perhatian dan minat murid dalam belajar. Dan dapat membangkitkan dunia teori dengan realitanya. ${ }^{7}$

Dengan demikian,konsepsi fungsi media dalam kegiatan mengajar tidak lagi semata-mata peraga dari guru, melainkan pembawa informasi atau pesan pembelajaran yang dibutuhkan siswa.Dengan begitu guru dapat lebih fokus dan berpusat pada pengembangan dan pengolahan individu dan kegiatan belajar mengajar. ${ }^{8}$

Media pembelajaran dapat meningkatkan kualitas pemahaman peserta didik dalam proses belajarnya, yang pada gilirannya diharapkan dapat meningkatkan prestasi belajar peserta didik. Ada beberapa alasan mengapa media pembelajaran dipandang dapat meningkatkan prestasi belajar peserta didik.

Pertama, berkenaan dengan manfaat media pembelajaran, dapat dijabarkan beberapa hal berikut: Pengajaran akan lebih menarik perhatian peserta didik sehingga dapat meningkatkan motivasi belajar. Bahan pengajaran akan lebih jelas maknanya sehingga dapat dipahami dan dikuasai oleh peserta didik. Metode pengajaran akan lebih variatif, tidak semata-mata komunikasi verbal. Peserta didik lebih banyak melakukan kegiatan belajar, sebab tidak hanya mendengar uraian guru, tetapi juga punya aktivitas lain seperti mengamati, merumuskan, melakukan dan mendemonstrasikan.

Kedua, penggunaan media pembelajaran dapat meningatkan kualitas proses dan hasil belajar yang berkenaan dengan taraf pikir siswa. ${ }^{9}$ Berfikir siswa dimulai dari yang konkret menuju yang abstrak, dari yang sederhana menuju yang kompleks. Dalam hubungan ini, penggunaan media pembelajaran berkaitan erat dengan tahapan-tahapan berfikir mereka sehingga penggunaan media pembelajaran harus disesuaikan dengan kondisi mereka, sehingga hal-hal yang abstrak dapat dikonkretkan.

${ }^{7}$ Ibid., hlm. 23-25.

${ }^{8}$ Yusuf Hadi Miarso dkk., Teknologi Komunikasi Pendidikan, Jakarta: Rajawali Pers, 1984.

${ }^{9}$ Nana Sudjana, Media Pendidikan, Bandung: Sinar Baru, 1990. 
Secara ringkas ada 2 jenis media pembelajaran, yaitu (1) media duadimensi dan (2) media tiga-dimensi.Jenis yang pertama adalah media duadimensi. Media ini adalah alat peraga yang hanya memiliki ukuran panjang dan lebar yang berada pada satu bidang datar, meliputi grafis, media bentuk papan, dan media cetak yang penampilan isinya tergolong dua dimensi. Media ini berupa media visual diam sehingga hanya dapat diterima melalui indra mata.Kelebihan dari media ini yaitubentuknya sederhana, ekonomis, bahan mudah diperoleh, dapat menyampaikan rangkuman, mampu mengatasi keterbatasan ruang dan waktu, tidak memerlukan peralatan khusus dan mudah penempatannya, sedikit memerlukan informasi tambahan, dapat divariasi antara media satu dengan yang lain.Adapun kekuarangan dari media ini adalah ia hanya dapat dilihat tampak depan,tidak dapat menjangkau kelompok besar,hanya menekankan persepsi indra penglihatan, dantidak menampilkan unsur audio dan motion. Contoh dari media 2-dimensi ialah (1) papan tulis, (2) papan tempel, (3) papan flanel, dan (4) papan magnet.

Selanjutnya, jenis media pembelajaran yang kedua adalah media 3dimensi. Moedjiono (1992) mengatakan, media sederhana tiga dimensi memiliki kelebihan-kelebihan, diantaranya adalah: (a) Memberikan pengalaman secara langsung, (b) Penyajian secara konkrit dan menghindari verbalisme, (c) Dapat menunjukkan objek secara utuh baik konstruksi maupun cara kerjanya, (d) Dapat memperlihatkan struktur organisasi secara jelas, (d) Dapat menunjukkan alur suatu proses secara jelas. Namun demikian, media 3-dimensi juga memiliki kelemahan-kelemahan seperti: (a) Tidak bisa menjangkau sasaran dalam jumlah besar, (b) Penyimpanannya memerlukan ruang yang besar, (c) Perawatannya rumit.

\section{MODEL ASSURE DAN PENGEMBANGAN MEDIA PEMBELAJARAN}

Untuk mendapatkan hasil yang maksimal dalam penerapan media pembelajaran ada baiknya kita memahami model ASSURE, yang merupakan suatu model formulasi Kegiatan Belajar Mengajar (KBM) berorientasi kelas. Model ASSURE yang diterapkan dalam penyusunan rencana pembelajaran, digagas pertama kali oleh Sharon E. Maldino, Deborah L. Lowther dan James D. Russell dalam bukunya yang berjudul Instructional Technology \& Media For Learning. Perencanaan pembelajaran model ASSURE meliputi 6 tahapan. ${ }^{10}$

10 Lihat Sumber: http:/ / ranto.staff.fkeip.uns.ac.id/2011. Diakses tanggal 24 Mei 2012 
Pertama, Analyze Learners. Tahap pertama ini dilakukan untuk mengetahui karakteristik tertentu dari sekelompok siswa. Ada 3 karakteristik yangperlu diperhatikan pada diri pembelajar, yaitu karakteristik umum, spesifikasi kemampuan awal, dan gaya belajar. 1) Karakteristik Umum. Yang termasuk dalam karakteristik umum adalah usia, jenis kelamin, tingkat pendidikan, pekerjaan, etnis, kebudayaan, dan faktor sosial ekonomi. Karakteristik umum ini dapat digunakan untuk menuntun kita dalam memilih metode, strategi dan media untuk pembelajaran. 2) Kedua, Spesifikasi Kemampuan Awal. Ini berkenaan dengan pengetahuan dan kemampuan yang sudah dimiliki pembelajar sebelumnya. Informasi ini dapat kita peroleh dengan memberikan entry test/ entry behavior kepada pembelajar sebelum kita melaksanakan pembelajaran. Hasil dari entry test ini dapat dijadikan acuan tentang hal-hal apa saja yang perlu dan tidak perlu lagi disampaikan kepada pembelajar. 3) Ketiga, Gaya Belajar. Gaya belajar timbul dari kenyamanan yang kita rasakan secara psikologis dan emosional saat berinteraksi dengan lingkungan belajar, karena itu gaya belajar siswa ada yang cenderung dengan audio, visual, atau kinestetik. Berkenaan gaya belajar ini, kita sebaiknya menyesuaikan metode dan media pembelajaran yang akan digunakan.

Kedua, State Standards and Objectives. Tahap kedua adalah merumuskan standar dan tujuan pembelajaran yang ingin dicapai.Standar diambil dari Standar Kompetensi yang sudah ditetapkan. Ketiga, Select Strategies, Media, and Materials. Tahap ketiga dalam merencanakan pembelajaran yang efektif adalah memilih strategi, teknologi, media dan materi pembelajaran yang sesuai. Strategi pembelajaran harus dipilih apakah yang berpusat pada siswa atau berpusat pada guru sekaligus menentukan metode yang akan digunakan. Keempat, Utilize Technology, Media and Materials. Tahap keempat adalah menggunakan teknologi, media dan material.Pada tahap ini melibatkan perencanaan peran kita sebagai guru dalam menggunakan teknologi, media dan materi. Untuk melakukan tahap ini ikuti proses “5P", yaitu: Pratinjau (preview), mengecek teknologi, media dan bahan yang akan digunakan untuk pembelajaran sesuai dengan tujuannya dan masih layak pakai atau tidak. Menyiapkan (prepare) teknologi, media dan materi yang mendukung pembelajaran kita. Mempersiapkan (prepare) lingkungan belajar sehingga mendukung penggunaan teknologi, media dan materi dalam proses pembelajaran. Mempersiapkan (prepare) pembelajar sehingga mereka siap belajar dan tentu saja akan diperoleh hasil belajar yang maksimal. Dan menyediakan (provide) pengalaman belajar (terpusat pada pengajar atau pembelajar), sehingga siswa memperoleh pengalaman belajar secara maksimal.

Kelima, Require Learner Participation. Tahap kelima adalah mengaktifkan partisipasi pembelajar.Belajar tidak cukup hanya mengetahui, tetapi harus bisa 
merasakan dan melaksanakan serta mengevaluasi hal-hal yang dipelajari sebagai hasil belajar. Dalam mengaktifkan pembelajar di dalam proses pembelajaran yang menggunakan teknologi, media dan materi alangkah baiknya kalau ada sentuhan psikologisnya, karena akan sangat menentukan proses dan keberhasilan belajar. Psikologi belajar dalam proses pembelajaran yang perlu diperhatikan adalah: Behavioris, karena tanggapan/respon yang sesuai dari pengajar dapat menguatkan stimulus yang ditampakkan pembelajar. Kognitifis, karena informasi yang diterima pembelajar dapat memperkaya skema mentalnya. Konstruktivis, karena pengetahuan dan ketrampilan yang diterima pembelajar akan lebih berarti dan bertahan lama di kepala jika mereka mengalami langsung setiap aktivitas dalam proses pembelajaran. Dan Sosial, karena feedback atau tanggapan yang diberikan pengajar atau teman dalam proses pembelajaran dapat dijadikan sebagai ajang untuk mengoreksi segala informasi yang telah diterima dan juga sebagai support secara emosional.

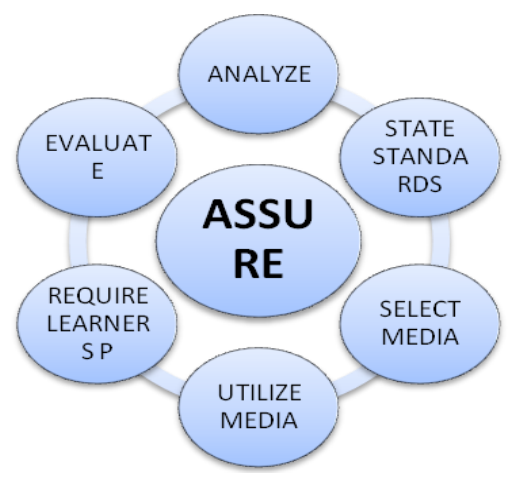

Gambar 1. Tahap/proses ASSURE

Keenam, Evaluate and Revise. Tahap keenam adalah mengevaluasi dan merevisi perencanaan pembelajaran serta pelaksanaannya.Evaluasi dan revisi dilakukan untuk melihat seberapa jauh teknologi, media dan materi yang kita pilih/gunakan dapat mencapai tujuan yang telah kita tetapkan sebelumnya. Dari hasil evaluasi akan diperoleh kesimpulan: apakah teknologi, media dan materi yang kita pilih sudah baik, atau harus diperbaiki lagi.

\section{MEDIA PEMBELAJARAN BERBASIS ICT}

ICT (Information and Communication Technology) atau dalam bahasa Indonesia diartikan sebagai Teknologi Informasi dan Komunikasi (TIK) adalah berbagai aspek yang melibatkan teknologi, rekayasa dan teknik pengolahan yang 
digunakan dalam pengendalian dan pemrosesan informasi serta penggunaannya, hubungan komputer dengan manusia dan hal yang berkaitan dengan sosial, ekonomi dan kebudayaan. ${ }^{11}$

Dengan begitu, ICT mencakup dua aspek yaitu teknologi informasi dan teknologi komunikasi. Teknologi informasi meliputi segala hal yang berkaitan dengan proses, penggunaan sebagai alat bantu, manipulasi, dan pengelolaan informasi. Sedangkan teknologi komunikasi adalah segala sesuatu yang berkaitan dengan penggunaan alat bantu untuk memproses dan mentransfer data dari perangkat yang satu ke lainnya. Jadi Teknologi Informasi dan Komunikasi mengandung pengertian luas yaitu segala kegiatan yang terkait dengan pemrosesan, manipulasi, pengelolaan, pemindahan informasi antar media.

Prinsip umum penggunaan teknologi, dalam hal ini ICT adalah sebagai berikut; pertama, Efektif dan efisien. Penggunaan ICT harus memperhatikan manfaat dari teknologi ini dalam hal mengefektifkan belajar, meliputi pemerolehan ilmu, kemudahan dan keterjangkauan, baik waktu maupun biaya. Kedua, Optimal.Dengan menggunakan ICT, paling tidak pembelajaran menjadi bernilai "lebih" daripada tanpa menggunakannya.Nilai lebih yang diberikan ICT adalah keluasan cakupan, kekinian, kemodernan dan keterbukaan. Ketiga, Menarik. Artinya dalam prinsip ini, pembelajaran di kelas akan lebih menarik dan memancing keingintahuan yang lebih. Pembelajaran yang tidak menarik dan memancing keingintahuan yang lebih akan berjalan membosankan dan kontra produktif untuk pembelajaran. Dan keempat, Merangsang daya kreatifitas berpikir pelajar. Dengan menggunakan ICT tentu saja diharapkan pelajar mampu menumbuhkan kreativitasnya dengan maksimal yang terdapat di dalam diri mereka.

Dengan demikian, tujuan ICTakan sejalan dengan tujuan pendidikan itu sendiri ketika digunakan dalam pembelajaran. Penggunaan ICT tidak justru menjadi penghambat dalam pembelajaran namun akan memberi manfaat yang lebih dalam pembelajaran.

Pada saat ini, pembelajaran ICT di lingkungan sekolah/universitas merupakan hal yang sangat penting. Hal ini dikarenakan semakin meningkatnya kebutuhan informasi dan komunikasi dalam berbagai keperluan seiring dengan perkembangan ilmu pengetahuan dan teknologi (IPTEK).ICT yang secara sederhana disimbolkan oleh perangkat komputer dan jaringan internet serta

11 British Advisory Council for applied Research and Development: Report on Information Technology; H.M. Stationery Office. 1980. 
perangkat komunikasi telah banyak dimanfaatkan untuk meningkatkan produktivitas kerja para pelajar mulai dari sekolah dasar hingga perguruan tinggi.

Salah satu bentuk produk ICT yang sedang menjadi "trend" adalah internet yang berkembang pesat di penghujung abad 20 dan awal abad 21 . Kehadiran internet telah memberikan dampak yang cukup besar terhadap kehidupan umat manusia dalam berbagai aspek dan dimensi. Internet merupakan salah satu instrumen dalam era globalisasi yang telah menjadikan dunia ini menjadi transparan dan terhubungkan dengan sangat mudah dan cepat tanpa mengenal batas-batas wilayah geografis dan negara. Melalui internet setiap orang dapat berkomunikasi. Bahkan, dunia pendidikan pun dapat dengan mudah untuk memanfaatkannya sehingga kelas maya pun dapat tercipta.

Hal yang paling mutakhir adalah berkembangnya apa yang disebut "cyber teaching” atau pengajaran maya, yaitu proses pengajaran yang dilakukan dengan menggunakan internet. Istilah lain yang makin populer saat ini ialah e-learning yaitu satu model pembelajaran dengan menggunakan media ICT khususnya internet. Dengan e-learning memungkinkan terjadinya proses belajar mengajar jarak jauh. E-learning merupakan dasar dari perkembangan teknologi informasi dan komunikasi.

E-learning mempermudah interaksi antara peserta didik dengan materi, peserta didik dengan pengajar maupun sesama peserta didik.Peserta didik dapat saling tukar informasi dan dapat mengakses bahan-bahan belajar setiap saat dan berulang-ulang.Dengan kondisi yang demikian itu peserta didik dapat lebih memantapkan penguasaanya terhadap materi pembelajaran.

Selaine-learning, potensi ICT dalam pembelajaran di sekolah dapat juga memanfaatkan e-laboratory dan e-library.Adanya laboratorium virtual (virtual lab) memungkinkan guru dan siswa dapat belajar menggunakan alat-alat laboratorium atau praktikum tidak di laboratorium secara fisik, tetapi dengan menggunakan media komputer.Perpustakaan elektronik (e-library) sekarang ini sudah menjangkau berbagai sumber buku yang tak terbatas untuk bisa diakses tanpa harus membeli buku/sumber belajar tersebut.

Beberapa aplikasi teknologi informasi dan komunikasi/ ICT dalam pengembangan pembelajaran yang dapat dikembangkan antara lain: pertama, Pembelajaran Berbasis Komputer. Pembelajaran berbasis komputer yaitu penggunaan komputer sebagai alat bantu dalam dunia pendidikan dan pengajaran. Penggunaan komputer secara langsung dengan peserta didik dapat dilakukan untuk menyampaikan isi pelajaran, memberikan latihan dan mengevaluasi kemajuan belajar peserta didik. Materi pembelajaran dibuat dalam bentuk Power Point atau CD pembelajaran interaktif. 
Kedua, E-Learning. Blended E-Learning adalah pembelajaran terintegrasi/ terpadu dengan menggunakan jaringan internet (network), intranet (LAN), atau ekstranet (WAN) sebagai pengantar materi, interaksi atau fasilitas. Blended E-Learning disebut juga online learning. Pada pembelajaran model ini pembelajaran dapat disajikan dalam format: (1) E-mail (pengajar dan peserta didik berinteraksi dalam pembelajaran dengan menggunakan fasilitas e-mail). (2) Mailing list/ grup diskusi, bisa menggunakan fasilitas e-mail atau fasilitas jejaring sosial seperti facebook atau twitter. (3) Mengunduh bahan ajar dari internet, peserta didik dapat mencari bahan ajar melalui internet untuk menambah pengetahuan tentang pokok bahasan yang sedang dipelajari. (4) Pembelajaran interaktif melalui web/blog. (5) Interactive Conferencing, berupa pembelajaran langsung jarak jauh.

Ketiga, Pembelajaran berbasis web. Sekolah harus menyediakan website sekolah yang diantaranya berisi materi-materi pelajaran. Setiap pengajar dapat memiliki blog sendiri yang berisi mata pelajaran yang diajarkan, bisa berkomunikasi tentang materi pelajaran dengan peserta didik di dunia maya, dengan demikian akan tercipta virtual class room (kelas dunia maya) yang dapat memotivasi dan menambah wawasan pengetahuan peserta didik.

Keempat, Penilaian berbasis ICT. Penilaian hasil belajar peserta didik memerlukan pengolahan dan analisis yang akurat, obyektif, transparan dan integral agar bisa dipertanggungjawabkan.Oleh karena itu perlu dikembangkan penilaian berbasis komputer yang bisa diakses oleh peserta didik, pengajar dan orang tua.

Kelima, Perpustakaan online. Salah satu strategi pelayanan perpustakaan berbasis komputer adalah perpustakaan online. Perpustakaan online adalah fasilitas perpustakaan dalam dunia digital yang ada di internet yang memungkinkan seorang pencari informasi dapat mengakses ke segala sumber ilmu pengetahuan dengan cara yang mudah tanpa adanya batasan waktu dan jarak.

Seiring berkembangnya zaman, ICT semakin digunakan di dunia pembelajaran, hal itu bisa terjadi karena ICT dirasa membawa keuntungan baik bagi pengajar maupun pelajar, keuntungan atau dampak positif dari pembelajaran yang menggunakan ICT tersebut antara lain adalah: Pelajar jadi lebih mudah dalam belajar, karena kebanyakan pelajar lebih suka praktek dibandingkan teori. Pengajar jadi lebih mudah mengajar dan mudah menyampaikan materi dengan membuat presentasi-presentasi. Bagi pelajar maupun pengajar, pemberian dan penerimaan materi atau tugas tidak harus bertatap muka, jadi jika pengajar berhalangan hadir tetap dapat memberi tugas 
atau materi melalui e-mail. Dalam membuat laporan, baik bagi pelajar maupun pengajar jadi lebih mudah karena jika memakai komputer akan mudah dikoreksi jika ada kesalahan. Dalam belajar, baik pengajar maupun pelajar akan lebih mudah mencari sumber karena adanya internet. Dan Pembelajaran yang menggunakan ICT bisa dibuat lebih menarik, misalnya dengan memunculkan gambar atau suara sehingga pelajar lebih antusias untuk belajar.

Segala sesuatu pasti ada dampak positif dan negatifnya, tidak terkecuali pembelajaran yang menggunakan ICT. Dampak negatif dari pembelajaran menggunakan ICT diantaranya: Pembelajaran yang menggunakan ICT hanya bisa dilaksanakan oleh sekolah yang mampu, bagi sekolah-sekolah yang kurang mampu akan ketinggalan, dan siswanya akan kesulitan jika mereka masuk ke sekolah lanjutan di kota besar yang sudah sering menggunakan ICT. Setiap pelajar harus mendapat fasilitas yang sama, jadi dalam pembelajaran yang menggunakan komputer, setiap pelajarnya harus memakai 1 komputer yang memadai, jika komputer yang dalam kondisi baik hanya sebagian, akan ada siswa yang hanya menonton, sehingga mereka tidak menguasai penggunaan komputer. Dalam pembelajaran, siswa-siswa yang tidak antusias dalam penerimaan materi sering kali lebih suka main game selama pembelajaran, sehingga mereka tidak konsentrasi dan tidak menerima materi yang diajarkan. Dalam pembelajaran yang menggunakan internet yang tidak dibatasi, sering kali pelajar menggunakan internet bukan untuk keperluan belajar, misalnya membuka situs youtube untuk menonton video dalam proses belajar.

Secara umum, perangkat yang diperlukan untuk mengembangkan media pembelajaran berbasis ICT meliputi perangkat keras (hardware) dan perangkat lunak (software). Perangkat keras dapat berupa: komputer, scanner, speaker, microfon, CD-ROM, DVD-ROM, flashdisk, kartu memori, kamera digital, kamera video dan sebagainya. Sedangkan perangkat lunak (software) yang dapat digunakan untuk mengembangkan media pembelajaran berbasis ICT saat ini sudah banyak tersedia, misalnya: MS Word: dapat digunakan untuk membuat tampilan tekstual (tulisan atau gambar). MS Power Point: dapat digunakan untuk membuat slide presentasi, mempunyai kemampuan menampilkan teks, suara, animasi, video, serta untuk membuat media interaktif dengan fasilitas hyperlink yang dimiliki. MS Excel: software pengolah lembar data, dapat digunakan untuk membuat media yang berupa grafik, maupun untuk membuat simulasi. Software untuk menggambar dan mengolah citra seperti MS Paint, Correl Draw, dll. Software pengolah video seperti MS Movie Maker, VideoLiead, dll. Software pengolah suara seperti MS Sound Recorder. Software untuk membuat animasi 
flash seperti Macromedia Flash. Bahasa pemrograman umum seperti Pascal, Delphi, Visual Basic, Java, dll.

\section{PEMANFAATAN MEDIAICT PADA LEMBAGATPQ}

Media pembelajaran berbasis ICT dapat diterapkan dalam proses belajar mengajar pada jalur pendidikan formal dan non-formal. Tulisan artikel ini hanya membahas pemanfaatannya pada pendidikan non-formal khususnya TPQ.Ini didasarkan pada hasil pengabdian yang penulis lakukan pada TPQ di wilayah kecamatan Ngaliyan kota Semarang pada tahun 2016 ini.

Berdasarkan survey yang penulis lakukan pada beberapa lembaga TPQ di wilayah kecamatan Ngaliyan kota Semarang di awal 2016, penulis menemukan fakta bahwa ada beberapa lembaga TPQ yang masih memiliki masalah serius di bidang pembelajaran, seperti penggunaan metode konvensional dengan ceramah yang monoton serta minim alat peraga dan media pembelajaran. Kondisi ini jelas tidak menguntungkan bagi perkembangan dan kemajuan peserta didik (santri TPQ).

Realitas di lapangan menyatakan bahwa lembaga pendidikan Taman Pendidikan Al-Quran (TPQ) memikul tanggung jawab besar untuk memberikan layanan pendidikan agama Islam dasar dan baca tulis al-Qur'an kepada anakanak santrinya supaya menjadi anak yang sholeh/ sholehah dan memiliki landasan agama yang kuat.Tetapi sayang, dalam kenyataannya pembelajaran yang dilaksanakan oleh guru-gurunya masih belum optimal karena menggunakan caracara konvensional dan tidak mengikuti perkembangan teknologi, sehingga pembelajaran yang dilakukan oleh guru-guru TPQ kurang menarik perhatian santri. Kondisi semacam ini juga terjadi di TPQ-TPQ yang berada di kecamatan Ngaliyan kota Semarang.

Setelah mengetahui permasalahan nyata yang dihadapi oleh beberapa lembaga TPQ di kecamatan Ngaliyan penulis berpandangan bahwa solusinya adalah mengadakan tindakan untuk meningkatkan performa dan kualitas pembelajaran guru-guru TPQ tersebut. Dari sudut pandang akademik ilmu keguruan, pembelajaran yang tidak profesional tanpa didukung alat peraga, tanpa media pembelajaran yang memadahi akan berdampak pada tidak optimalnya hasil pembelajaran. Gurulah yang menjadi faktor utama yang mampu mengendalikan dan menghidupkan suasana kelas saat pembelajaran, sedangkan murid dengan sendirinya akan mengikuti irama yang diciptakan oleh guru. Daya serap murid terhadap materi yang disampaikan oleh guru juga bisa tergantung dari cara guru menyampaikan materinya. Pakar pendidikan bernama Silberman 
mengatakan bahwa siswa yang belajar dengan cara mendengarkan maka ia akan lupa (what I hear, I forget), siswa yang belajar dengan cara melihat maka ia akan menjadi ingat (what I see, I remember), dan siswa yang belajar dengan cara melakukan maka ia menjadi paham (what I do I understand). ${ }^{12}$

Dari sini dapat dipahami bahwa tingkat penyerapan oleh siswa tidak sama ketika pembelajaran dilakukan dengan metode dan media pembelajaran yang berbeda. Ketika guru menyampaikan materi hanya dengan berceramah artinya murid hanya mendengar saja dan materi yang diserap dengan cara mendengar akan lebih cepat dilupakan. Ketika guru menyampaikan materi disertai penggunaan media pembelajaran, berarti murid akan mendengar sekaligus melihat apa yang ada di media pembelajaran atau alat peraga tersebut, maka penyerapannya lebih baik dibandingkan dengan pembelajaran tanpa alat peraga. Apabila guru di dalam pengajarannya disertai dengan praktik maka ingatan murid akan semakin baik lagi karena dia menjadi lebih paham.

Pembelajaran dangan cara konvensional misalnya dengan cara ceramah saja sudah waktunya untuk disesuaikan dengan perkembangan zaman.Penggunaan media pembelajaran sudah saatnya diterapkan untuk setiap pembelajaran, baik dalam pembelajaran di jalur pendidikan formal maupun nonformal.Karena itu saat pembelajaran guru harus kreatif dalam menggunakan metode dan media pembelajaran yang menarik.Berangkat dari landasan teori seperti ini, guru-guru TPQ yang menjadi sasaran pendampingan dilatih untuk membuat media pembelajaran yang baik sesuai dengan tuntutan dan perkembangan zaman.Atas dasar inilah penulis/ pengabdi memberikan pelatihan pembuatan media pembelajaran berbasis ICT (Information and Computer Technology) kepada guru-guru TPQ di kecamatan Ngaliyan kota Semarang supaya guru-guru TPQ tersebut dapat melaksanakan pembelajaran secara lebih efisien dan para santri lebih antusias sehingga materi yang diberikan bisa diserap oleh para santri secara optimal.

Dalam konteks pemberdayaan guru-guru TPQ dan dalam rangka meningkatkan hasil pembelajaranbagi para santri TPQ, maka sumber daya utama di TPQ yakni para gurunya harus di-upgrade kapasitasnya yakni dengan cara salah satunya adalah mereka dilatih membuat dan menggunakan media pembelajaran berbasasis ICT. Target terpenting dalam pelatihan ini adalah bagaimana menjadikan para guru TPQ tersebut memiliki pengetahuan, pemahaman dan ketrampilan dalam membuat media pembelajaran berbasis ICT.

12 Melvin Silberman, Active Learning: 101 Strategi Pembelajaran Aktif (Terjemah), Yogyakarta: YAPPENDIS, 2007. 
Pelatihan dilakukan melalui tatap muka antara narasumber dengan peserta (para guru TPQ) dengan metode ceramah, tanya jawab, simulasi, demonstrasi dan praktek pembuatan media pembelajaran berbasis ICT. Narasumber dalam pelatihan ini adalah dosen professional dari Fakultas Ilmu Tarbiyah dan Keguruan (FITK) Universitas Islam Negeri (UIN) Walisongo Semarang, yakni bapak H. Mursid, M.Ag.yang sudah memiliki pengalaman bertahun-tahun melatih guru-guru pada acara PLPG. Kegiatan pelatihan atau workshop pembuatan media pembelajaran berbasis ICTtersebut dilaksanakan di gedung TPQ Nurul Iman, Jl. Tanjungsari Utara, RT.07/V, Tambakaji, Ngaliyan, Semarang dalam waktu 1 hari yaitu Minggu (15 Mei 2016) dari pukul 07.30 16.30 WIB. Peserta kegiatan ini berjumlah 16 orang terdiri dari guru-guru TPQ di wilayah kecamatan Ngaliyan Kota Semarang yang dalam hal ini terwakili oleh 6 lembaga TPQ yang tersebar di 5 kelurahan berbeda di kecamatan Ngaliyan, yakni: (1) TPQ Nurul Iman di RT.07/V Kelurahan Tambakaji sebanyak 8 orang, (2) TPQ al-Fattah di Kelurahan Purwoyoso sebanyak 2 guru, (3) TPQ al-Azhar kelurahan Beringin, sebanyak 2 orang guru, (4) TPQ An-Nahl di Kelurahan Kalipancur sebanyak 2 guru, (5) TPQ Al-Arif di Kelurahan Wonosari sebanyak 1 guru, (6) TPQ Baitul Muttaqien di kelurahan Tambakaji RT.04/VI sebanyak 1 orang guru.

Alur pelatihan pembuatan media pembelajaran berbasis ICT bagi guru TPQ di wilayah kecamatan Ngaliyan kota Semarang tersebut meliputi proses sebagaimana dalam tabel 2 .

Adapun materi yang disampaikan dalam pelatihan ini meliputi: 1) Teori dan Konsep dasar mengenai media pembelajaran. 2) Media pembelajaran berbasis ICT (Fokus pada Power Point). 3) Praktik pembuatan media pembelajaran berbasis ICT (membuat Power Point dengan content materi pelajaran yang digunakan untuk pembelajaran di kelas). 4) Narasumber telah menambahkan pula lagu-lagu Islami untuk peserta didik PAUD dan TPQ dalam pelatihan tersebut. Selain itu, juga diperkenalkan pula cara menampilkan media pembelajaran berbasis ICT selain power point, yaitu 5) menggunakan video clip dari youtube yang berkaitan dengan materi sejarah Islam untuk pembelajaran di kelas.

Meskipun disampaikan dalam waktu yang relatif singkat namun para peserta sangat antusias mengikuti penjelasan dari narasumber.Masing-masing peserta memiliki tingkat kecepatan pemahaman yang berbeda-beda ada yang cepat dalam menangkap materi pelatihan namun ada juga yang agak lambat.Tetapi secara keseluruhan mereka dapat mempraktikkan pembuatan 
media pembelajaran berbasis ICT khususnya Power Point dengan materi pelajaran yang dipakai di kelas masing-masing secara baik.

\section{Tabel 2}

\begin{tabular}{|c|c|c|}
\hline Awal & Proses pelatihan & Hasil \\
\hline $\begin{array}{l}\text { Pengenalan dan } \\
\text { pengetahuan guru-guru } \\
\text { TPQ di kecamatan } \\
\text { Ngaliyan Kota } \\
\text { Semarang tentang } \\
\text { konsep Media } \\
\text { Pembelajaran berbasis } \\
I C T\end{array}$ & $\begin{array}{l}\text { Diperkenalkan: } \\
\text { 1. Pengantar pentingnya } \\
\text { media pembelajaran } \\
\text { 2. Teori ttg media } \\
\text { pembelajaran berbasis } \\
\text { ICT } \\
\text { 3. Pelatihan pembuatan } \\
\text { media pembelajaran } \\
\text { berbasis } I C T \\
\text { 4. Praktek pembuatan } \\
\text { media pembelajaran } \\
\text { berbasis } I C T\end{array}$ & $\begin{array}{l}\text { Bertambahnya } \\
\text { pengetahuan dan } \\
\text { ketrampilan } \\
\text { mengenai pembuatan } \\
\text { media pembelajaran } \\
\text { berbasis ICT bagi } \\
\text { guru-guru TPQ di } \\
\text { kecamatan Ngaliyan } \\
\text { Kota Semarang }\end{array}$ \\
\hline
\end{tabular}

Selanjutnya, evaluasi dilaksanakan setelah pelatihan, yaitu dengan cara setiap peserta pelatihan diperintahkan mencoba membuat media pembelajaran berbasis ICT secara mandiri.Sebagaimana dijelaskan pada bagian landasan teori, media pembelajaran berbasis ICTitu bentuknya beragam dan salah satu diantaranya adalah Power Point. Untuk pelatihan kali ini difokuskan pada praktek pembuatan Power Point dengan content materi pelajaran yang dipakai atau digunakan oleh guru di kelas TPQ masing-masing. Hasil dari evaluasi tersebut adalah hampir semua guru-guru TPQ (95\%)peserta pelatihan dapat membuat media pembelajaran berbasis ICT yakni dalam bentuk Power Point dengan content materi pelajaran yang akan dipakai di kelas.

Guru-guru TPQ peserta pelatihan ini mengikuti semua sesi dengan antusiasme tinggi, termasuk pada sesi praktek.Saat praktek para peserta melakukannya dengan serius, terbukti tidak ada peserta yang meninggalkan tempat pelatihan sampai akhir acara. Melihat anutisiasme peserta dan manfaat yang diperoleh peserta yang sangat besar dan penting bagi peningkatan hasil belajar para santri TPQ, maka penulis merekomendasikan adanya kegiatan lanjutan berupa pelatihan-pelatihan serupa secara reguler pada tahun-tahun yang akan datang. 
Secara garis besar dapat disimpulkan bahwa media pembelajaran berbasis ICT dapat digunakan dan dimanfaatkan untuk meningkatkan efisiensi dan efektivitas pembelajaran di kelas, tidak saja di lembaga pendidikan formal seperti sekolah tetapi juga yang non-formal seperti halnya TPQ. Pelatihan yang diberikan kepada para guru TPQ di kecamatan Ngaliyan kota Semarang dalam pembuatan media pembelajaran berbasis ICT membuktikan antusiasme mereka yang tinggi untuk mempelajari dan memahami apa itu media pembelajaran ICT, lalu mau menerapkan dan mempraktikkannya dalam proses pembelajaran di kelas pada TPQ masing-masing. Ada nilai tambah ketika guru TPQ menerapkan media pembelajaran berbasis ICT, meskipun dalam bentuk sederhana yakni Power Point.Nilai tambah tersebut ialah penggunaan media pembelajaran berbasis ICT pada lembaga pendidikan non-formal TPQ dapat meningkatkan minat belajar para santri karena pembelajaran lebih menarik. Dari sisi guru, mereka juga merasa tertantang untuk dapat menampilkan materi pembelajaran dengan kemasan yang lebih menarik melalui media Power Point dan sekaligus mendorong mereka untuk mengenal dan menggunakan teknologi modern, sehingga kelasnya pun menjadi hidup dan dinamis.

\section{KESIMPULAN}

Seiring dengan perkembangan zaman, dimana ilmu pengetahuan dan teknologi telah berkembang begitu pesat, maka pihak-pihak yang terlibat dalam dunia pendidikan terutama para guru harus mampu beradaptasi dengan teknologi saat ini. Media pembelajaran berbasis Information and Commuinication Technology (ICT) sudah saatnya dikenalkan dan dikuasai oleh para guru untuk kemudian dimanfaatkan dalam proses pembelajaran di kelas agar materi yang disampaikan bisa diserap murid secara optimal.Pembelajaran yang disertai dengan alat peraga atau media pembelajaran yang baik dan memadahi terbukti secara teori memperoleh hasil yang lebih baik.Kondisi ini berlaku tidak saja pada pembelajaran yang terjadi dalam pendidikan jalur formal seperti di sekolah, namun juga di jalur pendidikan non-formal seperti TPQ.Penulis berpandangan bahwa penting untuk memperkuat kapasitas dan kapabilitas guru TPQ dalam proses belajar mengajar dengan menerapkan media pembelajaran berbasis ICT(misal, berupa power point). Penggunaan media pembelajaran berbasis ICT oleh guru-guru TPQ di dalam kelas akan dapat merangsang keaktifan peserta didik dan mempermudah guru dalam menyampaikan materi yang diajarkannya, karena materi sudah dipersiapkan terlebih dahulu dalam bentuk Power Point sehingga guru tinggal menyampaikan saja sehingga lebih efektif dan efisien. 


\section{DAFTAR PUSTAKA}

Asnawir, Media Pendidikan, Jakarta: Ciputat Press, 2002.

Danim, Sudarman, Media Komunikasi Pendidikan, Jakarta: Bumi Aksara, 1995.

Dawit, M. Yusuf, Komunikasi Pendidikan, Bandung: Remaja Rosdakarya, 1990.

Idris, Zahara, Dasar-Dasar Pendidikan, Padang: Angkasa Raya, 1981.

Junaidi, Modul Pengembangan ICT (Information Communication Technology), Jakarta:

Direktorat Pendidikan Agama Islam, Dirjen Pendidikan Islam, Kementerian Agama RI, 2011.

Miarso, Yusuf Hadi, dkk., Teknologi Komunikasi Pendidikan, Jakarta: Rajawali Press, 1984.

Nasution, S., Teknologi Pendidikan, Bandung: Jemars, 1983.

Pribadi, Benni Agus, Media Pendidikan, Jakarta: Universitas Terbuka, 1996.

Sadiman, Arief S., dkk. Media pendidikan: pengertian, pengembangan, dan pemanfaatannya. Jakarta: PT Raja Grafindo Persada, 2012.

Silberman, Melvin, Active Learning: 101 Strategi Pembelajaran Aktif (Terjemah), Yogyakarta: YAPPENDIS, 2007.

Sudjana, Nana, Media Pendidikan, Bandung: Sinar Baru, 1990.

Syukur, Fatah, Teknologi Pendidikan, Semarang: RoSail, 2005. 